\title{
Trial tests Austrian integrity body
}

Unfair-dismissal suit will show whether the young agency's rulings are taken seriously.

\section{BY ALISON ABBOTT}

A ustria's fledgling science-integrity agency is facing its first big test, as a protein crystallographer it found guilty of misconduct sues his university for unfair dismissal. If the court upholds the university's move, it would bolster the agency's efforts to change attitudes towards misconduct in the country's universities.

The Austrian Agency for Scientific Integrity was created in 2008 in response to a particularly serious case of misconduct at the Medical University of Innsbruck, where clinical trials of a stem-cell therapy were carried out without ethics approval ${ }^{1}$. By the end of 2011, the agency - an association of universities and research institutes - had dealt with a total of 46 cases, and formally investigated 15 of them. Most involved plagiarism or authorship conflicts, and two involved data manipulation.

The case of crystallographer Robert Schwarzenbacher, which it investigated earlier this year, is by far the most serious yet, says Christoph Kratky, a structural biologist at the University of Graz and chair of the agency's board. It is also the first to have serious consequences for the person accused: Schwarzenbacher lost his job at the University of Salzburg after the agency signalled its conclusion that he was guilty of data fabrication.

The case revolves around a paper coauthored by Schwarzenbacher in the Journal of Immunology, which described the molecular structure of a version of a birch-pollen allergen $^{2}$. An article submitted to Acta Crystallographica in January pointed out "physically improbable" features in the structure. That article was published in April ${ }^{3}$, along with a response from the original authors saying that "Schwarzenbacher admits to the allegations of data fabrication and deeply apologizes to the co-authors and the scientific community" . However, a note added in proof says that Schwarzenbacher had withdrawn his admission of fabrication.

When Heinrich Schmidinger, the rector at the University of Salzburg, learned about the concerns at the end of January, he contacted the integrity agency for its opinion on the case. "The case was clear because Schwarzen-

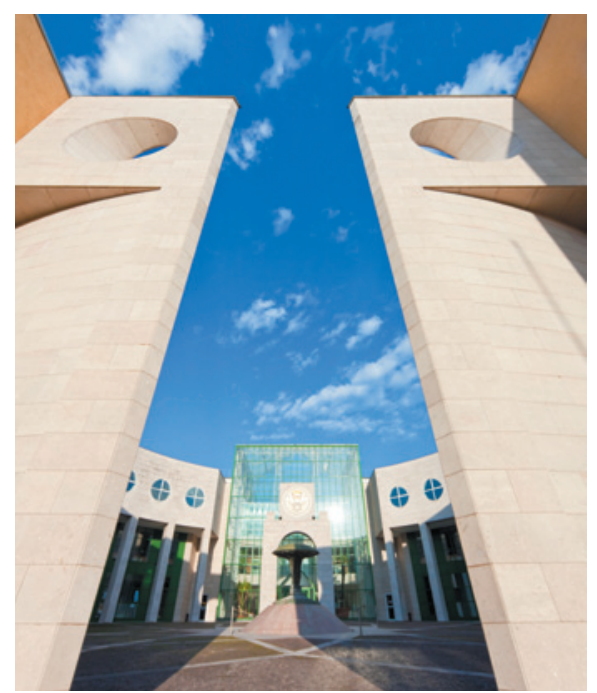

The University of Salzburg will defend in court its dismissal of Robert Schwarzenbacher.

bacher had admitted to fabrication, and the agency's investigation confirmed misconduct," says Schmidinger, who on 22 March gave Schwarzenbacher three months' notice.

Schmidinger says that he was particularly concerned about preserving the university's reputation. Recalling highly critical reports of the Innsbruck scandal in Nature ${ }^{5}$, he says, "I didn't want my university to be referred to in that way in the English-language press."

Schwarzenbacher now says that the data in question were merely wrong and not fabricated. He is taking the university to court because, he argues, a single case of incorrect data in a publication should not outweigh the benefit to the university's reputation brought by his nearly
100 genuine papers, as well as the large grants that he has won in the past. Schwarzenbacher also claims that "the rector cancelled my contract before the agency reached a conclusion - I cannot see any fairness in [this] conduct". Schmidinger says that the agency had informed him of its verdict before the dismissal, although it did not issue its formal report until early April.

Austrian professors were once civil servants, with jobs almost guaranteed for life a situation, still common in many European countries, that can make it very difficult to sack an academic ${ }^{6}$. But since a change in the law in 2002, academics in Austrian universities have had normal contracts that allow the university to dismiss them if they are deemed "unworthy of the confidence of the employer".

Schwarzenbacher's case, to be heard later this month, will be the first dispute centred on scientific misconduct to come before a labour court. "We'll find out if the courts will accept this type of misconduct as grounds for dismissal, and if they will take the judgements of the agency seriously," says Kratky.

Although universities are not legally bound to accept the agency's judgements, Kratky says that the agency has "raised consciousness" about scientific misconduct, which has historically been swept under the carpet in Austria. "There is much less cynicism among university rectors" about tackling it, he says, although the agency's formal judgements are not always taken on board by universities.

If the labour court upholds the right of the University of Salzburg to dismiss Schwarzenbacher, other universities will be encouraged to punish misconduct, Kratky says. If it does not, he plans to push for a change to the agency's legal basis, to give its decisions teeth. -

1. Abbott, A. Nature 454, 922-923 (2008).

2. Zaborsky, N. et al. J. Immunol. 184, 725-735 (2010).

3. Rupp, B. Acta Crystallogr. F 68, 366-376 (2012)

4. Zaborsky, N. et al. Acta Crystallogr. F 68, 377 (2012)

5. Nature 454, 917-918 (2008).

6. Abbott, A. Nature 477, 384 (2011).

\section{\begin{tabular}{l|l} 
TOP STORY & \\
& $\begin{array}{l}\text { Petition gathers } \\
\text { names in bid to } \\
\text { get diabetes drug }\end{array}$ \\
Victoza banned \\
over cancer \\
concerns go.nature. \\
com/7uu2tu
\end{tabular}}

\section{MORE NEWS}

- FDA finds non-compliance with rules on clinical-trial data not to be a major problem go.nature.com/mruaxb - Drug-resistant bacteria go undetected go.nature.com/mtwzql - Sunny outlook for space-weather forecasters go.nature.com/to8j2c

\section{MUSE}

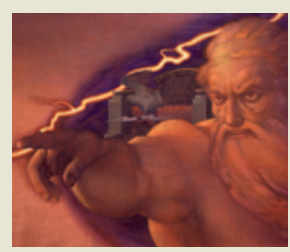

Is it true that rationality is the enemy of religion? go.nature.com/ valin4 